\title{
Ibuprofen Modulates NF-KB Activity but Not IL-8 Production in Cystic Fibrosis Respiratory Epithelial Cells
}

\author{
Nurlan Dauletbaev ${ }^{\mathrm{a}} \quad$ Joyce Lam ${ }^{\mathrm{a}} \quad$ Daniel Eklove $^{\mathrm{a}} \quad$ Michele Iskandar $^{\mathrm{a}} \quad$ Larry C. Lands $^{\mathrm{a}, \mathrm{b}}$ \\ ${ }^{a}$ Research Institute, McGill University Health Centre, and b Division of Respiratory Medicine, Montreal Children's Hospital, \\ Montreal, Que., Canada
}

For editorial comment see p. 189

\section{Key Words}

Corticosteroids - Cystic fibrosis - Dexamethasone ·

Epithelial cells $\cdot$ Ibuprofen $\cdot \mathrm{IL}-1 \beta \cdot \mathrm{IL}-8 \cdot \mathrm{NF}-\kappa \mathrm{B} \cdot \mathrm{NSAIDS} \cdot$

TNF- $\alpha \cdot$ Transcription factors

\begin{abstract}
Background: High-dose ibuprofen is clinically effective in cystic fibrosis (CF); however, its molecular mechanisms are poorly understood. Objective: To test the hypothesis that clinically relevant concentrations of ibuprofen suppress activation of nuclear factor (NF)- $\mathrm{KB}$ and thus down-regulate stimulated interleukin (IL)-8 production in CF respiratory epithelial cells. Methods: The majority of experiments were conducted in CFTE29o- cells (F508del-mutated CF transmembrane regulator, CFTR). Key experiments were confirmed in CFBE41o- cells (F508del-mutated CFTR) and 1HAEo- cells (wild-type CFTR). NF- $\kappa B$ and IL-8 were stimulated with tumour necrosis factor (TNF)- $\alpha$ or IL-1 $\beta$. NF- $\kappa B$ and IL-8 suppression by ibuprofen ( $480 \mu \mathrm{M})$ was compared to dexamethasone (5 nM). Results: Both TNF- $\alpha$ and IL-1 $\beta$ activated NF- $\kappa \mathrm{B}$ and stimulated IL-8 production. Both ibuprofen and dexamethasone demonstrated comparably modest suppression of NF- $\mathrm{KB}$ transcriptional activity. However, ibuprofen had no effect on stimulated IL-8 mRNA and protein. By contrast, dexamethasone significantly down-regulated stimulated IL-8 mRNA and protein. Conclusions: The pres-
\end{abstract}

ent data do not support the hypothesis that ibuprofen down-regulates IL-8 production in response to TNF- $\alpha$ and $\mathrm{IL}-1 \beta$ in CF respiratory epithelium. Suppression of NF- $\mathrm{KB}$ transcriptional activity does not discriminate between antiinflammatory drugs with or without effects on IL-8 production. We speculate that NF-kB-independent mechanisms may be responsible for anti-IL-8 effects of dexamethasone.

Copyright $\odot 2009$ S. Karger AG, Basel

\section{Introduction}

Cystic fibrosis $(\mathrm{CF})$ is a lethal genetic disease characterised by progressive lung damage due to chronic infection and exaggerated airway inflammation. Current antiinflammatory therapies for $\mathrm{CF}$ include corticosteroids [1-3] and ibuprofen [4, 5], a non-steroidal anti-inflammatory drug (NSAID). These drugs slow decline in pulmonary function and exert other beneficial clinical effects. Unfortunately, serious adverse effects (corticosteroids [6]), or concerns thereof (ibuprofen [7]) have limited their clinical use. Therefore, there is a need to develop novel and safer anti-inflammatory drugs for CF. A better un-

J.L. and D.E. contributed equally to this study and should be considered co-second authors.

\section{KARGER}

Fax +4161306 1234 E-Mail karger@karger.ch www.karger.com (c) 2009 S. Karger AG, Basel

0025-7931/10/0793-0234\$26.00/0

Accessible online at:

www.karger.com/res
Larry C. Lands, MD, PhD

Division of Respiratory Medicine

Montreal Children's Hospital, Room D-380

2300 Tupper Street, Montreal, QC H3H 1 P3 (Canada)

Tel. +1 514412 4444, Fax +1 514412 4364, E-Mail larry.lands@ muhc.mcgill.ca 
derstanding of molecular mechanisms of existing anti-inflammatory therapies could help to create future drugs.

The inflammation in CF airways is neutrophil dominated. The factors released by activated neutrophils are believed to cause lung damage. Neutrophils are recruited to $\mathrm{CF}$ airways by overabundant interleukin (IL)- 8 , which is the principal neutrophil-chemo-attracting agent [8]. For instance, in CF nasal epithelium, the presence of neutrophils correlated well with the expression of IL-8 mRNA [9].

CF respiratory epithelium secretes exaggerated amounts of IL-8, either spontaneously $[10,11]$ or in response to pro-inflammatory cytokines $[12,13]$. Downregulation of IL-8 production in CF respiratory epithelium could attenuate neutrophil-dominated inflammation and its negative consequences in the CF lung.

In $\mathrm{CF}$, ibuprofen is administered at high doses to achieve a specific range of concentrations in serum (50$100 \mathrm{mg} / \mathrm{l}[4,5])$. These concentrations diminish neutrophil migration [14]. At these concentrations, ibuprofen is believed to target intracellular pathways beyond suppression of prostaglandin synthesis $[7,15]$. In particular, ibuprofen has been shown to down-regulate production of leukotriene 4 via yet unknown mechanisms [16]. Further, several CF-unrelated studies indicate that high-dose ibuprofen suppresses activity of nuclear factor (NF)- $\kappa \mathrm{B}[17-$ 19]. NF- $\kappa B$ is the major transcription factor activating IL-8 production in response to many CF-relevant inflammatory factors, such as tumour necrosis factor (TNF)- $\alpha$ and IL-1 $\beta$ [20]. The suppression of NF-kB activation and subsequent down-regulation of IL-8 could explain the decrease of neutrophil migration in CF patients treated with ibuprofen [14].

We hypothesised that CF-relevant concentrations of ibuprofen suppress NF- $\kappa \mathrm{B}$ activation in response to TNF$\alpha$ and IL- $1 \beta$ and thus down-regulate stimulated IL- 8 production in CF respiratory epithelium. We tested this hypothesis in a respiratory epithelial cell line (CFTE29o-) [21] which expresses the most common CF mutation (F508del) [22]. Key experiments were confirmed in another CF respiratory epithelial cell line (CFBE41o-; F508del) [23], as well as in a 1HAEo- respiratory epithelial cell line expressing wild-type CF transmembrane regulator (CFTR) [24]. Anti-IL-8 activity of high-dose ibuprofen was compared to that of dexamethasone, a corticosteroid, which has a well-established record of IL-8 down-regulation in respiratory epithelium [25]. Both drugs were used at clinically relevant concentrations: ibuprofen at $100 \mathrm{mg} / \mathrm{l}(480 \mu \mathrm{M})[4,5]$ and dexamethasone at $1.7 \mu \mathrm{g} / \mathrm{l}(5 \mathrm{nM})[26,27]$.

Ibuprofen Suppresses NF-кB but Not IL-8

\section{Materials and Methods}

\section{Reagents}

Ibuprofen was from Cayman Chemicals. Similar to the clinical drug, it is a racemic (i.e. 1:1) mixture of $\mathrm{S}(+)$ and $\mathrm{R}(-)$ enantiomers of ibuprofen. Dexamethasone was from Sigma. Both drugs were prepared as stocks in absolute ethanol (200 and $1 \mathrm{mM}$, respectively) and stored at $-20^{\circ} \mathrm{C}$. Ethanol was used as a diluent control in these experiments. $\mathrm{S}(+)$-ibuprofen, the more active enantiomer of ibuprofen, was from Sigma. S(+)-ibuprofen was solubilised freshly in PBS (4.85 mM), and PBS was used as a diluent control. Human recombinant TNF- $\alpha$ and IL- $1 \beta$ were from BD Biosciences. Unless otherwise specified, reagents were obtained from Sigma.

\section{Cell Lines}

For the majority of experiments, we used the CFTE29o- cell line expressing F508del-mutated CFTR [21]. Key experiments were confirmed in CFBE41o- cell line (F508del) [23] and 1HAEocell line, a non-CF cell line [24]. All cell lines were a kind gift from Dr. Dieter Gruenert (University of California at San Francisco).

Basal cell culture was maintained in coated $[21,28]$ flasks in minimal essential medium supplemented with $10 \%$ fetal bovine serum, antibiotics and $2 \mathrm{mM}$ L-glutamine. Subconfluent cells were trypsinised [21], collected and counted. Unless otherwise specified, cell concentration was adjusted to $0.25 \times 10^{6}$ viable (trypan blue exclusion) cells $/ \mathrm{ml}$. Cells were plated, cultured overnight to $95-100 \%$ confluency, and used in the experiments in antibiotics-free minimal essential medium supplemented with $0.5 \%$ bovine serum albumin and $2 \mathrm{mM} \mathrm{L}$-glutamine.

\section{IL-8 ELISA}

Cells grown on 24-well plates were pre-incubated (30 min to $16 \mathrm{~h})$ with culture medium with or without test drugs. Then, TNF- $\alpha$ or IL- $1 \beta$ were added ( $10 \mathrm{ng} / \mathrm{ml}$ final solution), and cells were stimulated for $1 \mathrm{~h}$. After removal of inflammatory stimuli, cells were cultured in the presence or absence of test drugs for another $4 \mathrm{~h}$. Cell culture supernatants were collected and analysed for IL- 8 by ELISA (BD Biosciences).

\section{IL-8 mRNA Expression}

Cells grown on 6-well plates were pre-incubated for $30 \mathrm{~min}$ with culture medium with or without test drugs and stimulated with TNF- $\alpha$ or IL-1 1 (both at $10 \mathrm{ng} / \mathrm{ml}$ ) for $1 \mathrm{~h}$. At the end of stimulation, cells were lysed with TRIzol (Invitrogen). Total RNA was extracted, and $1 \mu \mathrm{g}$ of total RNA was reverse transcribed with QuantiTect reverse transcription kit (Qiagen). IL-8 mRNA expression was quantified by real-time quantitative PCR (qPCR). Primer sets (IL- 8 and $\beta$-actin) and QuantiFast Sybr Green PCR kit were from Qiagen. PCR reactions $(25 \mu \mathrm{l})$ were conducted using $1.5 \mu \mathrm{l}$ of cDNA on Mx3000 qPCR system (Stratagene). The comparative threshold cycle $\left(\mathrm{C}_{\mathrm{T}}\right)$ method was used for relative quantification of PCR products [29] after IL- 8 was normalised to $\beta$ $\operatorname{actin}\left(\Delta \mathrm{Ct}=\mathrm{Ct}_{\mathrm{IL}-8}-\mathrm{Ct}_{\beta \text {-actin }}\right)$. IL-8 mRNA data in treated samples were expressed in fold changes over controls: fold change treated sample $=2^{-\Delta \Delta \mathrm{Ct}}$, where $\Delta \Delta \mathrm{Ct}=\Delta \mathrm{Ct}_{\text {treated sample }}-$ $\Delta \mathrm{Ct}_{\text {control }}$.

NF- $\mathrm{B}$ p 65 Nuclear Translocation and Binding Activity

Nuclear translocation of NF- $\kappa$ B p65 in response to TNF- $\alpha$ or IL-1 $\beta$ was confirmed by immunostaining experiments. 
Fig. 1. TNF- $\alpha$ and IL- $1 \beta$ stimulate IL- 8 in CFTE29o- (a) and CFBE41o- (b) cells. CF respiratory epithelial cells were stimulated for $1 \mathrm{~h}$ with culture medium (basal), or 10 ng/ml TNF- $\alpha$ (TNF) or IL-1 $\beta$ (IL-1). After removal of stimuli, cells were cultured for $4 \mathrm{~h}$, and IL- 8 in supernatants was measured by ELISA. $\mathrm{n}=3-4,{ }^{*} \mathrm{p}<0.05$ vs. basal. Data are means + SEM.

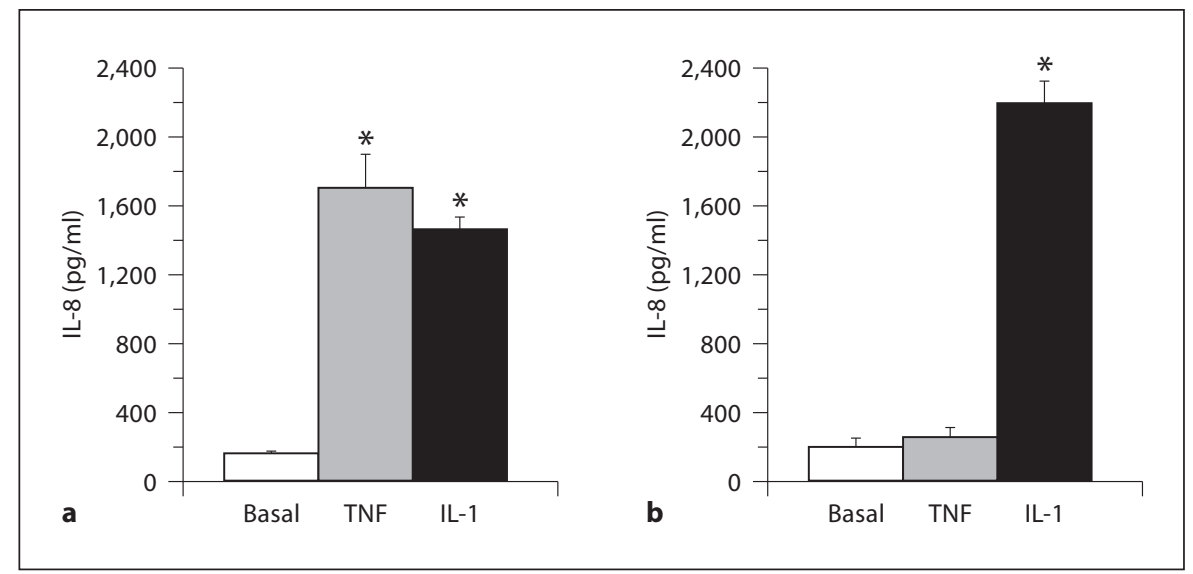

CFTE29o- cells were plated onto 12-mm glass coverslips and grown as above. Cells were stimulated with TNF- $\alpha$ or IL-1 $\beta$ (both at $10 \mathrm{ng} / \mathrm{ml}$ ) for $1 \mathrm{~h}$ and used in immunofluorescent staining. Cells were washed with PBS and fixed for $30 \mathrm{~min}$ in methanol-free $4 \%$ formaldehyde, freshly prepared from $16 \%$ stock (Polysciences). Then, cells were permeabilised for $20 \mathrm{~min}$ with pre-chilled $\left(-20^{\circ} \mathrm{C}\right)$ absolute methanol and washed with PBS. Unspecific binding was blocked by $1 \%$ BSA in PBS (30 min). NF- $\kappa$ B p65 was immunodetected using rabbit anti-p65 antibody (Santa Cruz, $1: 200$ in $1 \%$ BSA, overnight staining), biotinylated goat anti-rabbit antibody (Santa Cruz, 1:200, $45 \mathrm{~min}$ ) and streptavidin-Alexa Fluor 488 conjugate (Invitrogen, 1:100, $45 \mathrm{~min}$ ). Immunofluorescence was visualised and documented using Axio Imager fluorescence microscope from Zeiss.

For NF- $\kappa$ B p65 binding activity, CFTE29o- cells were grown on $60-\mathrm{mm}$ culture dishes, pre-incubated for $30 \mathrm{~min}$ with culture medium with or without test drugs, and stimulated with TNF- $\alpha$ or IL-1 $\beta$ (both at $10 \mathrm{ng} / \mathrm{ml}$ ) for $1 \mathrm{~h}$. Cell nuclei were obtained immediately after $1 \mathrm{~h}$ stimulation using Nuclear Extraction kit (Active Motif). Protein concentrations were quantified using BCA protein assay (Pierce Endogen). Five-microgram nuclear extracts were used in the NF- $\kappa$ B p65 Trans AM assay (Active Motif).

\section{NF- $\kappa B$ Transcriptional Activity: Transient Transfection and}

\section{Reporter Gene Assay}

For a high-efficiency transient transfection, we used a Nucleofector II device (Amaxa). CFTE29o- cells were collected by trypsinisation, pelleted by centrifugation $(90 \mathrm{~g}, 10 \mathrm{~min})$ and counted. Two million viable cells were re-pelleted by centrifugation $(90 \mathrm{~g}$, $10 \mathrm{~min}$ ) and reconstituted in $100 \mu \mathrm{l}$ of Nucleofector Solution V (Nucleofector Kit V, Amaxa). Cells were electroporated in the presence of $1.0 \mu \mathrm{g}$ of NF- $\mathrm{KB}$ firefly luciferase Rapid Response Reporter (Promega) and $0.1 \mu \mathrm{g}$ of internal control (Renilla luciferase reporter, HSV-TK constitutive promoter; Promega) using program T-020. The NF- $\kappa$ B firefly luciferase Rapid Response Reporter contains five NF- $\kappa \mathrm{B}$-binding elements. This reporter also contains protein degradation sequences for a quicker reporter turnover and a more accurate assessment of NF- $\kappa$ B transcriptional activity.

Transfected cells were plated onto a 96-well plate (quadriplicate wells/outcome) at a concentration of $1.0 \times 10^{6}$ viable cells/ $\mathrm{ml}$. Cells were cultured for $24 \mathrm{~h}$, pre-incubated for $30 \mathrm{~min}$ with culture medium with or without test drugs, and stimulated with TNF- $\alpha$ or IL- $1 \beta$ (both at $10 \mathrm{ng} / \mathrm{ml}$ ) for $1 \mathrm{~h}$. After removal of inflammatory stimuli, cells were cultured with or without test drugs for another $4 \mathrm{~h}$ and lysed with Passive Lysis Buffer (Promega). Luminescence was quantified using Dual-Luciferase Reporter Assay System (Promega) on Glomax microplate luminometer (Promega). Relative luciferase activity was calculated by normalising firefly luciferase activity against Renilla luciferase activity.

This transfection protocol provided high $(\sim 80 \%)$ transfection efficiency as judged by transfection experiments with plasmids encoding for green fluorescent protein (data not shown).

\section{Statistical Analysis}

Statistical analysis was conducted with Statistica 6.0 software (StatSoft). The results are presented as means + SEM. Differences were assessed by the Mann-Whitney U non-parametric test. In some graphs, data are presented as percent or fold change over respective controls. For these graphs, statistical significance was calculated prior to presentation as percent or fold change. The level of statistical confidence was set at $\mathrm{p}<0.05$.

\section{Results}

\section{TNF- $\alpha$ and IL- $1 \beta$ Stimulate IL- 8 and NF- $\kappa B$}

In CFTE29o- cells, stimulation for $1 \mathrm{~h}$ with TNF- $\alpha$ or IL-1 $\beta$ significantly up-regulated IL-8 production, as detected $4 \mathrm{~h}$ later ( $\mathrm{p}<0.05$ vs. basal, both comparisons; fig. 1a). The magnitude of IL-8 up-regulation was comparable between both inflammatory stimuli (fig. 1a).

CFBE41o- cells slightly up-regulated IL-8 production in response to stimulation with $10 \mathrm{ng} / \mathrm{ml} \mathrm{TNF-} \alpha$. However, this up-regulation did not reach statistical significance ( $p>0.05$ vs. basal; fig. 1b). In contrast, CFBE41osignificantly increased IL-8 production after stimulation with IL-1 $\beta$ ( $p<0.05$ vs. basal; fig. $1 b$ ). The magnitude of 


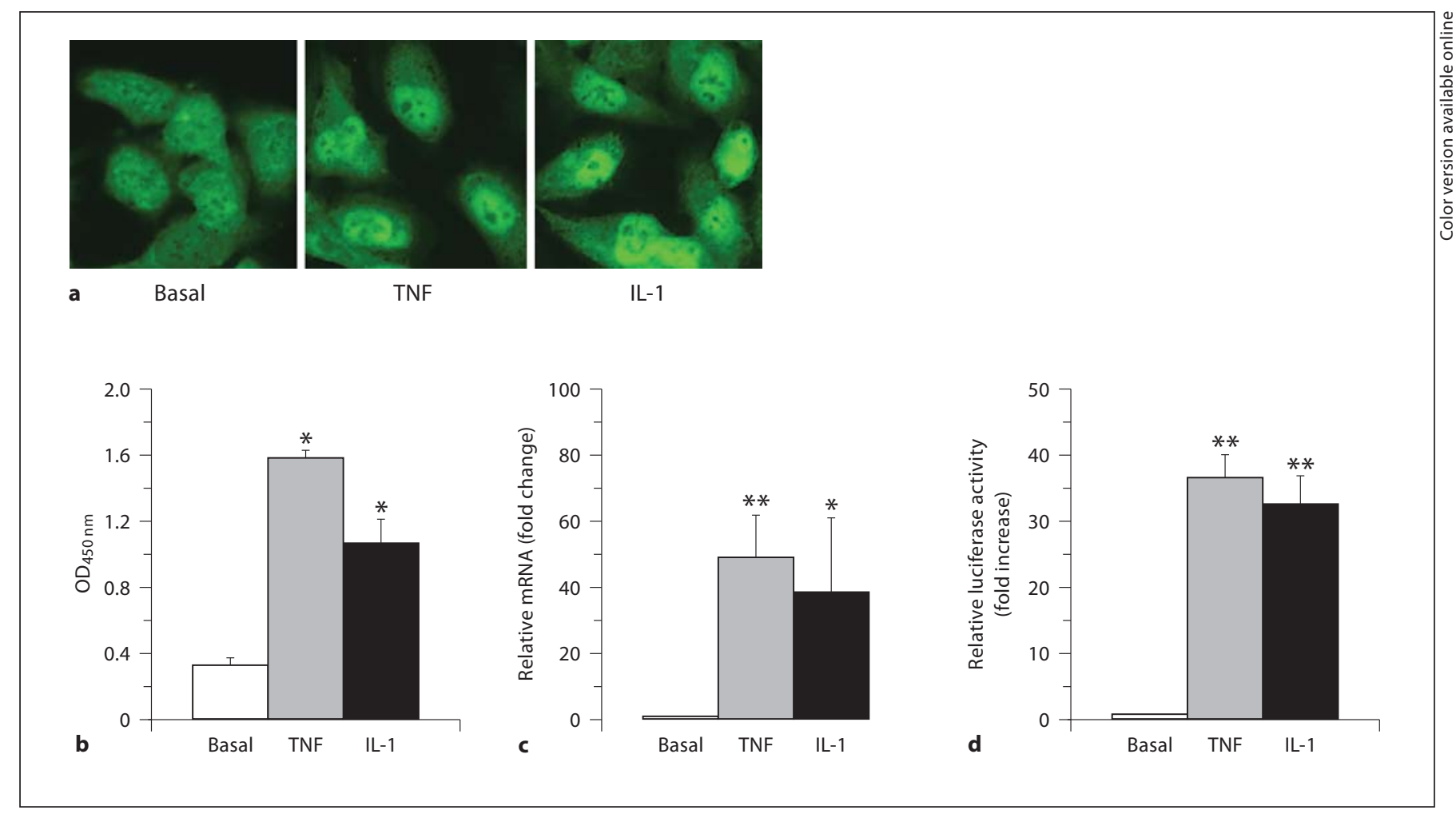

Fig. 2. TNF- $\alpha$ and IL-1 $\beta$ stimulate NF- $\kappa$ B activation and IL- 8 mRNA transcription in CFTE29o- cells. CFTE29o- cells were stimulated for $1 \mathrm{~h}$ with culture medium (basal), or $10 \mathrm{ng} / \mathrm{ml} \mathrm{TNF}$ $\alpha$ (TNF) or IL-1 $\beta$ (IL-1). Immediately after stimulation, NF- $\kappa$ B p65 nuclear translocation was documented by immunofluorescence (a) and nuclear extracts were analyzed for NF- $\mathrm{B}$ p 65 binding activity by TransAM assay (b). $\mathrm{n}=3-4,{ }^{*} \mathrm{p}<0.05$ vs. basal. c Immediately after stimulation, cells were analysed for IL-8 mRNA expression by qPCR. The IL- 8 mRNA expression of cells stimulated with TNF- $\alpha$ or IL-1 $\beta$ was expressed in fold change over basal. $\mathrm{n}=3-5,{ }^{*} \mathrm{p}<0.05$ vs. basal, ${ }^{* *} \mathrm{p}<0.01$ vs. basal. d Cells expressing NF- $\mathrm{KB}$ luciferase reporter were stimulated for $1 \mathrm{~h}$, cultured for $4 \mathrm{~h}$ without stimuli and analysed for luciferase activity. $\mathrm{n}=7-8,{ }^{* *} \mathrm{p}<0.01$ vs. basal. Data are means + SEM.
IL-8 up-regulation that we observed $4 \mathrm{~h}$ after stimulation with $10 \mathrm{ng} / \mathrm{ml} \mathrm{IL-1 \beta}$ (12-fold increase) was comparable to the one reported by John et al. [30] in response to $100 \mathrm{ng} /$ $\mathrm{ml}$ TNF- $\alpha$ (estimated 12- to 15 -fold increase, $24 \mathrm{~h}$ after stimulation). These findings suggest that CFBE41o- cells are weak-to-moderate responders to TNF- $\alpha$ and vigorous responders to IL- $1 \beta$.

The activation of NF- $\mathrm{KB}$ by two inflammatory stimuli was followed in CFTE29o-cells because this cell line was a vigorous responder to both TNF- $\alpha$ and IL-1 $1 \beta$. First, we documented nuclear translocation of NF- $\kappa$ B p 65 after $1 \mathrm{~h}$ of stimulation with either inflammatory stimulus (fig. 2a). This observation was further confirmed by increased p65-binding activity in nuclei of stimulated CFTE29o- cells ( $p<0.05$, both comparisons; fig. $2 b$ ).

As expected, the NF- $\kappa \mathrm{B}$ p 65 nuclear translocation and increase in binding activity was associated with increased IL-8 mRNA transcription. This was true for both TNF- $\alpha$ and IL-1 $\beta$ ( $p<0.01$ or $<0.05$ vs. basal, respectively; fig. $2 c)$. Further, both TNF- $\alpha$ and IL-1 $\beta$ increased NF- $\kappa$ B transcriptional activity in CFTE29o- cells (luciferase reporter studies; $\mathrm{p}<0.01$ vs. basal, both comparisons; fig. 1d).

To summarise, CFTE29o- cells responded with activation of NF- $\kappa \mathrm{B}$ and up-regulation of IL-8 production after stimulation with both TNF- $\alpha$ and IL-1 $\beta$. Therefore, this cell line was used for the majority of subsequent studies.

\section{Ibuprofen Suppresses NF- $\kappa B$ Transcriptional Activity,}

but Not Stimulated IL-8 Production

Respiratory epithelial cell lines were pre-incubated with clinically relevant concentrations of ibuprofen or dexamethasone, and stimulated with TNF- $\alpha$ or IL-1 $\beta$. Ibuprofen was tested as a racemic mixture [i.e. a 1:1 mixture of $\mathrm{S}(+): \mathrm{R}(-)$ enantiomers], or as $\mathrm{S}(+)$-ibuprofen (the more active enantiomer). 
In the first experiment, CFTE29o- and CFBE41ocells were pre-incubated for $30 \mathrm{~min}$ with diluent or test drugs and stimulated for $1 \mathrm{~h}$ with TNF- $\alpha$ or IL- $1 \beta$. Then, inflammatory stimuli were removed, and cells were incubated with diluent or test drugs for $4 \mathrm{~h}$. After this incubation, IL-8 production was quantified by ELISA.

Ibuprofen had no effect on stimulated IL-8 production in CFTE29o- or CFBE41o- cells ( $p>0.05$ vs. diluent + TNF or diluent + IL-1; fig. 3a-c). In marked contrast, dexamethasone significantly decreased stimulated IL-8 production in both CFTE29o- ( $p<0.01$ vs. diluent + TNF or diluent + IL-1; fig. 3a, b) and CFBE41o- cells ( $p<0.05$ vs. diluent + IL-1; fig. 3c). In CFTE29o- cells, the anti-IL- 8 potency of ibuprofen was not increased by a longer ( $90 \mathrm{~min}$ to $16 \mathrm{~h}$ ) pre-incubation with this drug ( $p>0.05$ vs. diluent + TNF, data not shown).

We next wanted to rule out that insensitivity to highdose ibuprofen in CFTE29o- and CFBE41o- cells was due to CF gene defect. Therefore, we tested this drug in 1 HAEo- cell line which expresses wild-type CFTR. Similar to CF cell lines, ibuprofen failed to decrease stimulated IL- 8 production in 1 HAEo- cells ( $p>0.05$ vs. diluent + TNF; fig. 3d).

We also tested whether $\mathrm{S}(+)$-ibuprofen, the more active enantiomer of ibuprofen, would be capable of suppressing IL-8 production. S(+)-ibuprofen makes up two thirds of total ibuprofen in serum [31]; therefore, $100 \mathrm{mg} / \mathrm{l}$ of total ibuprofen contain $66 \mathrm{mg} / \mathrm{l}(320 \mu \mathrm{M})$ of $\mathrm{S}(+)$-ibuprofen. At this concentration, $\mathrm{S}(+)$-ibuprofen did not suppress stimulated IL-8 production in CFTE29o- cells ( $p>0.05$ vs. diluent + TNF; fig. 3e).

The lack of IL- 8 suppression by ibuprofen was corroborated by studies on IL- 8 mRNA expression in CFTE29ocells. Specifically, ibuprofen did not suppress IL- 8 mRNA expression after 1-hour stimulation with TNF- $\alpha$ ( $p>0.05$ vs. diluent + TNF; fig. 4a).

By contrast, dexamethasone significantly decreased TNF- $\alpha$-stimulated IL- 8 mRNA expression ( $p<0.05$ vs. diluent + TNF; fig. 4a).

In subsequent experiments, we compared the effects of both ibuprofen and dexamethasone on NF- $\kappa \mathrm{B}$ activation. In the CFTE29o- cell line, neither ibuprofen nor dexamethasone suppressed NF- $\kappa \mathrm{B}$ p 65 binding activity after $1 \mathrm{~h}$ of stimulation with TNF- $\alpha$ ( $\mathrm{p}>0.05$ vs. diluent + TNF, both comparisons; fig. 4b). Interestingly, both ibuprofen and dexamethasone moderately decreased NF$\kappa \mathrm{B}$ transcriptional activity in luciferase reporter studies $(\mathrm{p}<0.05$ ibuprofen + TNF vs. diluent + TNF, $p<0.01$, dexamethasone + TNF vs. diluent + TNF; fig. 4c). The magnitude of these decreases did not differ significantly between both drugs ( $p>0.05$; fig. $4 \mathrm{c})$ and was within the range observed in previous reports [32-34].

To summarise, both high-dose ibuprofen and dexamethasone moderately decreased NF- $\mathrm{BB}$ transcriptional activity, yet only dexamethasone significantly decreased stimulated IL-8 production in CF respiratory epithelial cells.

\section{Discussion}

High-dose ibuprofen is effective clinically in CF; however, its molecular mechanisms are poorly understood. In the present study, we tested the hypothesis that high-dose ibuprofen suppresses NF- $\kappa \mathrm{B}$ activity and thus decreases stimulated IL-8 production in CF respiratory epithelium. Anti-IL-8 activity of ibuprofen was compared to that of dexamethasone, a well-established anti-IL-8 drug.

Both high-dose ibuprofen and dexamethasone modestly suppressed NF- $\kappa \mathrm{B}$ transcriptional activity in CF respiratory epithelial cells, but only dexamethasone significantly down-regulated stimulated IL-8 at both mRNA and protein levels. The lack of IL- 8 down-regulation by high-dose ibuprofen was documented in two CF respiratory epithelial cells, CFTE29o- and CFBE41o- cells, and in one respiratory epithelial cell line expressing wild-type CFTR, 1HAEo-.

Interestingly, we observed that CF respiratory epithelial cell lines demonstrate differential response to inflammatory stimuli. Specifically, CFTE29o- cells vigorously up-regulated IL- 8 in response to both TNF- $\alpha$ and IL$1 \beta$, whereas CFBE41o- cells responded only to IL-1 $\beta$ in the present study. John et al. [30] have observed that CFBE4lo- respond to $100 \mathrm{ng} / \mathrm{ml}$ TNF- $\alpha$. The ten times higher concentration of TNF- $\alpha$ and a longer incubation time after the stimulation ( 24 vs. $4 \mathrm{~h}$ in our study) are the likely reasons behind this discrepancy between our and their data. The heterogeneity of inflammatory responses among CF respiratory epithelial cell lines underscores the necessity of testing several cell lines and different inflammatory stimuli, such as done in the present study.

Since high-dose ibuprofen is incapable of down-regulating stimulated IL-8 in CF respiratory epithelium, there must be alternative molecular mechanisms for ibuprofen in CF. These molecular mechanisms may involve inactivation of the transcription factor $\mathrm{C} / \mathrm{EPB}$ homologous protein (CHOP). In CF, this transcription factor appears to be involved in at least two pathways.

The first pathway is directly related to the F508del mutation. In this mutation, accumulation of misfolded CFTR 


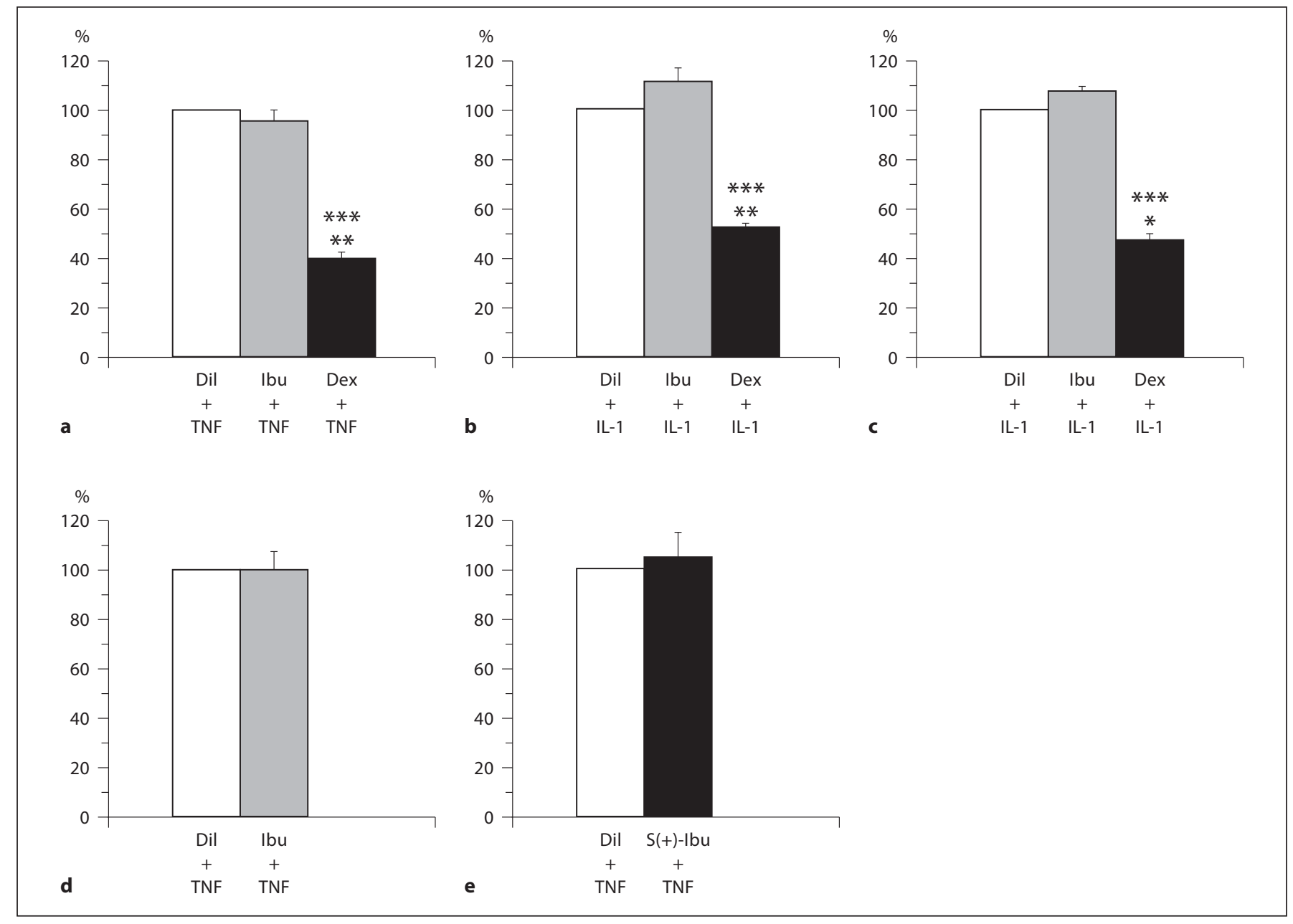

Fig. 3. Dexamethasone (Dex; $5 \mathrm{nM}$ ) but not $480 \mu \mathrm{M}$ ibuprofen or $320 \mu \mathrm{M} \mathrm{S}(+)$-ibuprofen (Ibu) down-regulate IL-8 production in respiratory epithelial cells stimulated with TNF- $\alpha$ or IL-1 $\beta$. a CFTE29o- cells were pre-treated for $30 \mathrm{~min}$ with diluent (Dil) or test drugs, and stimulated for $1 \mathrm{~h}$ with $10 \mathrm{ng} / \mathrm{ml} \mathrm{TNF}-\alpha$ (TNF). After removal of TNF, CFTE29o- cells were incubated with Dil or test drugs for $4 \mathrm{~h}$, and IL- 8 in supernatants was measured by ELISA. The IL- 8 data of cells treated with test drugs + TNF were expressed as percent of Dil + TNF. $n=6,{ }^{* *} \mathrm{p}<0.01$ (Dex + TNF vs. Dil + TNF), ${ }^{* *} \mathrm{p}<0.01$ (Dex + TNF vs. Ibu + TNF). b CFTE29o- were pre-treated for $30 \mathrm{~min}$ with Dil or test drugs, and stimulated for $1 \mathrm{~h}$ with $10 \mathrm{ng} / \mathrm{ml} \mathrm{IL}-1 \beta$ (IL-1). After removal of IL-1, cells were processed as described in a. The IL-8 data of cells treated with test drugs + IL-1 were expressed as percent of Dil + IL-1. n $=6,{ }^{* *} \mathrm{p}<0.01$ (Dex + IL-1 vs. Dil + IL-1), ${ }^{* *} \mathrm{p}<$
0.01 (Dex + IL-1 vs. Ibu + IL-1). c CFBE41o- cells were pre-treated for 30 min with Dil or test drugs, and stimulated for $1 \mathrm{~h}$ with $10 \mathrm{ng} / \mathrm{ml} \mathrm{IL-1.} \mathrm{After} \mathrm{removal} \mathrm{of} \mathrm{IL-1,} \mathrm{cells} \mathrm{were} \mathrm{processed} \mathrm{as} \mathrm{de-}$ scribed in a. The IL- 8 data of cells treated with test drugs + IL-1 were expressed as percent of Dil + IL-1. $n=4,{ }^{*} \mathrm{p}<0.05$ (Dex + IL-1 vs. Dil + IL-1), ${ }^{* * *} \mathrm{p}<0.05$ (Dex + IL-1 vs. Ibu + IL-1). d 1 HAEo- cells were pre-treated for $30 \mathrm{~min}$ with Dil or test drugs, and stimulated for $1 \mathrm{~h}$ with $10 \mathrm{ng} / \mathrm{ml} \mathrm{TNF}$. After removal of TNF, cells were processed as described in a. The IL- 8 data of cells treated with Ibu + TNF were expressed as percent of Dil + TNF. $\mathrm{n}=5$. e CFTE29o- cells were pre-treated for 30 min with Dil or S(+)ibuprofen [S(+)-Ibu] and stimulated for $1 \mathrm{~h}$ with $10 \mathrm{ng} / \mathrm{ml}$ TNF. After removal of TNF, cells were processed as described in $\mathbf{a}$. The IL-8 data of cells treated with test drugs + TNF were expressed as percent of Dil + TNF. $n=4$. Data are means + SEM. causes endoplasmatic reticulum (ER) stress [35]. This ER stress leads to chronic IL-8 overproduction by CF respiratory epithelium [36] via activation of the transcription factor CHOP [37] in the absence of inflammatory stimuli. One could speculate that ibuprofen may clinically sup- press this inflammatory pathway by blocking $\mathrm{CHOP}$ activity, as it was demonstrated with regard to NS398 [38].

Next, ibuprofen, as a COX2 inhibitor, could work by suppressing prostaglandin (PG) $\mathrm{E}_{2}$ synthesis in CF respiratory epithelium. $\mathrm{PGE}_{2}$ stimulates IL-8 production in 


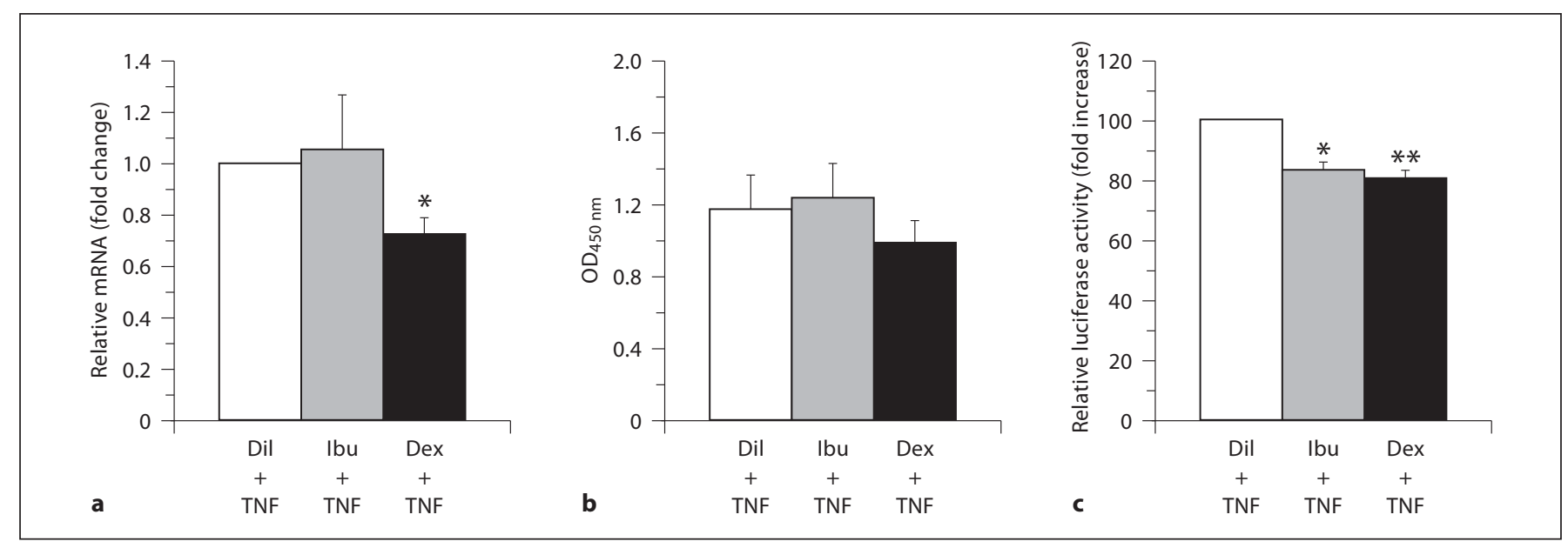

Fig. 4. Dexamethasone (Dex; $5 \mathrm{nM}$ ) suppresses NF-kB transcriptional activation and IL-8 mRNA transcription, whereas $480 \mu \mathrm{M}$ ibuprofen (Ibu) only suppresses NF- $\kappa$ B transcriptional activity in CFTE29o- cells stimulated with TNF- $\alpha$ (TNF). a Cells were pretreated for $30 \mathrm{~min}$ with diluent (Dil) or test drugs, and stimulated for $1 \mathrm{~h}$ with $10 \mathrm{ng} / \mathrm{ml}$ TNF. Immediately after stimulation with TNF, cells were analyzed for IL- 8 mRNA expression by qPCR. The IL- 8 mRNA expression in cells treated with test drugs + TNF was expressed in fold change over Dil + TNF. $\mathrm{n}=4,{ }^{*} \mathrm{p}<0.05$ (Dex + TNF vs. Dil + TNF). b Immediately after stimulation with TNF, nuclear extracts were analyzed for NF- $\mathrm{B}$ p 65 binding activity by TransAM assay. $n=5$. c Cells expressing NF- $\kappa$ B firefly luciferase reporter were pre-treated with Dil or test drugs for $30 \mathrm{~min}$ and stimulated for $1 \mathrm{~h}$ with 10/ml TNF. After removal of TNF, cells were incubated with Dil or test drugs for $4 \mathrm{~h}$, and analyzed for luciferase activity. The NF- $\kappa \mathrm{B}$ transcriptional activity in cells treated with test drugs + TNF was expressed in percent of Dil + TNF. $\mathrm{n}=7,{ }^{*} \mathrm{p}<0.05$ (Ibu + TNF vs. Dil + TNF), ${ }^{* *} \mathrm{p}<0.01$ (Dex + TNF vs. Dil + TNF). Data are means + SEM.
CF respiratory epithelial cells by activating CHOP [38]. In contrast to TNF- $\alpha$ and IL- $1 \beta, \mathrm{PGE}_{2}$ up-regulates IL- 8 only after prolonged (36-hour) stimulation [38]. Further, the magnitude of IL-8 up-regulation in response to $\mathrm{PGE}_{2}$ ( $\sim 1.5$ - to 2 -fold increase) [38] is significantly less prominent compared to the IL- 8 up-regulation by TNF- $\alpha$ or IL-1 $\beta$ (in the present study: at least 10-fold increase for both stimuli after $1 \mathrm{~h}$ of stimulation). Therefore, it is possible that ibuprofen is ineffective against acute and strong stimuli (e.g. TNF- $\alpha$ or IL-1 $\beta$ ), but capable of down-regulating IL-8 production in CF respiratory epithelium in response to chronic stimuli, such as ER stress or exposure to $\mathrm{PGE}_{2}$. This suppression of $\mathrm{PGE}_{2}$-related pathway was demonstrated with another NSAID, NS-398 [38]. Decrease in IL-8 production due to diminished ER stress or attenuated response to $\mathrm{PGE}_{2}$ could explain the in vivo suppression of neutrophil migration [14]. Alternatively, high-dose ibuprofen may directly target neutrophils and affect their functional properties, such as migration potential [39].

Next, clinical effects of ibuprofen may not be related to NF- $\kappa \mathrm{B}$ or $\mathrm{CHOP}$. There is a recent report demonstrating that ibuprofen at clinically relevant concentrations $(300 \mu \mathrm{M})$ enhances CFTR function [40].
CFTR is the ion channel whose malfunction is believed to trigger or aggravate the clinical disease because of the hindered transport of ions, electrolytes and antioxidants [41, 42]. Augmentation of CFTR function is expected to attenuate CF lung disease.

In addition, high-dose ibuprofen was reported to down-regulate cAMP activation in CF respiratory epithelium [38]. Suppression of cAMP-dependent pathway could be another anti-inflammatory mechanism of ibuprofen.

Both CF respiratory epithelial cell lines (CFTE29oand CFBE41o-) responded well to treatment with dexamethasone by decreasing stimulated IL-8 production. Our data are consistent with previous reports in the literature that CF cell lines and primary cultures are responsive to corticosteroids [43-45]. There are also publications reporting insensitivity of CF tracheobronchial gland serous cells to corticosteroids [46, 47]. Since tracheobronchial gland serous cells are abundant in CFTR [48], these cells can innately exist at a higher pro-inflammatory state than mucosal cells, and hence be less sensitive to corticosteroids.

The present findings show that modulation of NF- $\mathrm{BB}$ transcriptional activity in CF respiratory epithelial cells 
not always results in a down-regulation of IL-8 production in response to TNF- $\alpha$ and IL- $1 \beta$. Therefore, our data suggest that anti-inflammatory drugs require NF- $\kappa \mathrm{B}$-independent mechanisms to suppress stimulated IL-8 production in CF respiratory epithelium.

These NF- $\kappa \mathrm{B}$-independent mechanisms can encompass other transcription factors or post-transcriptional mechanisms.

In respiratory epithelium, stimulation with TNF- $\alpha$ activates both NF- $\mathrm{\kappa B}$ and activator protein (AP)-1 [49]. Dexamethasone has been reported to suppress AP-1 binding activity [50]. The IL-8 promoter contains an AP1 binding site [51], and IL- 8 production can be up-regulated by activation of AP-1 [20]. Therefore, dexamethasone can down-regulate IL- 8 production in CF respiratory epithelium by suppressing AP-1 activity. By contrast, we are not aware of any reports on such effects of ibuprofen on AP-1.

Alternatively, IL-8 production can be regulated by dexamethasone post-transcriptionally, e.g. by modulation of mRNA stability [52]. Modulation of IL-8 mRNA stability by dexamethasone could explain that only this drug affected the IL-8 mRNA expression while both ibuprofen and dexamethasone equally suppressed the NF-kB transcriptional activity. We are not aware of any reports demonstrating the mRNA-destabilizing effects of ibuprofen.
There are some limitations to our study. First, the present in vitro experiments were conducted in cell lines, and not in primary cell culture. Second, we used inflammatory cytokines to elicit IL- 8 response. It would be of interest to confirm the lack of anti-IL-8 activity of highdose ibuprofen in CF respiratory epithelium exposed to bacterial pathogens, such as Pseudomonas aeruginosa.

In conclusion, suppression of NF- $\kappa \mathrm{B}$ transcriptional activity by high-dose ibuprofen does not result in a decreased IL- 8 production in response to TNF- $\alpha$ or IL-1 $\beta$ in CF respiratory epithelial cells. Other biochemical mechanisms are likely to be responsible for the beneficial clinical effects of this drug in CF. The anti-IL- 8 activity of dexamethasone appears to be dissociated from its effects on NF- $\kappa \mathrm{B}$ and may involve NF- $\kappa \mathrm{B}$-independent mechanisms. More studies are needed to specify these mechanisms in CF respiratory epithelium.

\section{Acknowledgments}

The authors thank Dr. Dieter Gruenert for his kind gift of cell lines, and Mr. Shawn Mohammed and Ms. Heather Hopkins for assistance with preliminary experiments. This study was funded by the 'BREATHE' Initiative of Canadian Cystic Fibrosis Foundation.

\section{References}

-1 Auerbach HS, Williams M, Kirkpatrick JA, Colten HR: Alternate-day prednisone reduces morbidity and improves pulmonary function in cystic fibrosis. Lancet 1985;2:686688

2 Eigen H, Rosenstein BJ, FitzSimmons S, Schidlow DV: A multicenter study of alternate-day prednisone therapy in patients with cystic fibrosis. Cystic Fibrosis Foundation Prednisone Trial Group. J Pediatr 1995;126: 515-523.

-3 Greally P, Hussain MJ, Vergani D, Price JF: Interleukin-1 alpha, soluble interleukin-2 receptor, and IgG concentrations in cystic fibrosis treated with prednisolone. Arch Dis Child 1994;71:35-39.

4 Konstan MW, Byard PJ, Hoppel CL, Davis PB: Effect of high-dose ibuprofen in patients with cystic fibrosis. N Engl J Med 1995;332: 848-854.

5 Lands LC, Milner R, Cantin AM, Manson D, Corey M: High-dose ibuprofen in cystic fibrosis: Canadian safety and effectiveness trial. J Pediatr 2007;151:249-254.

-6 Lai HC, FitzSimmons SC, Allen DB, Kosorok MR, Rosenstein BJ, Campbell PW, Farrell PM: Risk of persistent growth impairment after alternate-day prednisone treatment in children with cystic fibrosis. N Engl J Med 2000;342:851-859.

7 Chmiel JF, Konstan MW: Inflammation and anti-inflammatory therapies for cystic fibrosis. Clin Chest Med 2007;28:331-346.

8 Kobayashi Y: The role of chemokines in neutrophil biology. Front Biosci 2008;13:24002407.

\$ Dauletbaev N, Gropp R, Frye M, Loitsch S, Wagner TO, Bargon J: Expression of human beta defensin (HBD-1 and HBD-2) mRNA in nasal epithelia of adult cystic fibrosis patients, healthy individuals, and individuals with acute cold. Respiration 2002;69:46-51.

$\checkmark 10$ Perez A, Issler AC, Cotton CU, Kelley TJ, Verkman AS, Davis PB: CFTR inhibition mimics the cystic fibrosis inflammatory profile. Am J Physiol Lung Cell Mol Physiol 2007;292:L383-L395.

-11 Tirouvanziam R, de Bentzmann S, Hubeau C, Hinnrasky J, Jacquot J, Peault B, Puchelle E: Inflammation and infection in naive human cystic fibrosis airway grafts. Am J Respir Cell Mol Biol 2000;23:121-127.

12 Muselet-Charlier C, Roque T, Boncoeur E, Chadelat K, Clement A, Jacquot J, Tabary O:
Enhanced IL-1 $\beta$-induced IL-8 production in cystic fibrosis lung epithelial cells is dependent of both mitogen-activated protein kinases and NF- $\mathrm{KB}$ signaling. Biochem Biophys Res Commun 2007;357:402-407.

13 Stecenko AA, King G, Torii K, Breyer RM, Dworski R, Blackwell TS, Christman JW, Brigham KL: Dysregulated cytokine production in human cystic fibrosis bronchial epithelial cells. Inflammation 2001;25:145-155.

14 Konstan MW, Krenicky JE, Finney MR, Kirchner HL, Hilliard KA, Hilliard JB, Davis PB, Hoppel CL: Effect of ibuprofen on neutrophil migration in vivo in cystic fibrosis and healthy subjects. J Pharmacol Exp Ther 2003;306:1086-1091.

15 Tegeder I, Pfeilschifter J, Geisslinger G: Cyclooxygenase-independent actions of cyclooxygenase inhibitors. FASEB J 2001; 15:20572072.

16 Konstan MW, Vargo KM, Davis PB: Ibuprofen attenuates the inflammatory response to Pseudomonas aeruginosa in a rat model of chronic pulmonary infection. Implications for antiinflammatory therapy in cystic fibrosis. Am Rev Respir Dis 1990;141:186192. 
17 Palayoor ST, Youmell MY, Calderwood SK, Coleman CN, Price BD: Constitutive activation of I $\kappa$ B kinase $\alpha$ and NF- $\kappa$ B in prostate cancer cells is inhibited by ibuprofen. Oncogene 1999;18:7389-7394.

- 18 Scheuren N, Bang H, Munster T, Brune K, Pahl A: Modulation of transcription factor NF- $\kappa \mathrm{B}$ by enantiomers of the nonsteroidal drug ibuprofen. Br J Pharmacol 1998;123: 645-652.

19 Stuhlmeier KM, Li H, Kao JJ: Ibuprofen: new explanation for an old phenomenon. Biochem Pharmacol 1999;57:313-320.

-20 Roebuck KA: Regulation of interleukin-8 gene expression. J Interferon Cytokine Res 1999;19:429-438.

-21 Kunzelmann K, Schwiebert EM, Zeitlin PL, Kuo WL, Stanton BA, Gruenert DC: An immortalized cystic fibrosis tracheal epithelial cell line homozygous for the delta F508 CFTR mutation. Am J Respir Cell Mol Biol 1993;8:522-529.

22 Southern KW: Cystic fibrosis and formes frustes of CFTR-related disease. Respiration 2007;74:241-251.

23 Gruenert DC: Human airway epithelial cell lines and concomitant journal references. http://www.cpmc.org/professionals/research/programs/science/celllinereference. pdf.

24 Cozens AL, Yezzi MJ, Yamaya M, Steiger D, Wagner JA, Garber SS, Chin L, Simon EM, Cutting GR, Gardner P: A transformed human epithelial cell line that retains tight junctions post crisis. In Vitro Cell Dev Biol 1992:28:735-744.

-25 Mukaida N, Morita M, Ishikawa Y, Rice N, Okamoto S, Kasahara T, Matsushima K: Novel mechanism of glucocorticoid-mediated gene repression. Nuclear factor-kappa B is target for glucocorticoid-mediated interleukin 8 gene repression. J Biol Chem 1994; 269:13289-13295.

26 Huizenga NA, Koper JW, de Lange P, Pols HA, Stolk RP, Grobbee DE, de Jong FH, Lamberts SW: Interperson variability but intraperson stability of baseline plasma cortisol concentrations, and its relation to feedback sensitivity of the hypothalamopituitary-adrenal axis to a low dose of dexamethasone in elderly individuals. J Clin Endocrinol Metab 1998;83:47-54.

-27 Weijtens O, Schoemaker RC, Cohen AF, Romijn FP, Lentjes EG, van Rooij J, van Meurs JC: Dexamethasone concentration in vitreous and serum after oral administration. Am J Ophthalmol 1998;125:673-679.

-28 Gruenert DC, Basbaum CB, Welsh MJ, Li M, Finkbeiner WE, Nadel JA: Characterization of human tracheal epithelial cells transformed by an origin-defective simian virus 40. Proc Natl Acad Sci USA 1988;85:59515955.
29 Livak KJ, Schmittgen TD: Analysis of relative gene expression data using real-time quantitative PCR and the $2^{-\Delta \Delta C_{\mathrm{T}}}$ method. Methods 2001;25:402-408.

30 John G, Yildirim AO, Rubin BK, Gruenert DC, Henke MO: Toll-like receptor (TLR)-4 mediated innate immunity is reduced in cystic fibrosis airway cells. Am J Respir Cell Mol Biol, E-pub ahead of print.

31 Dong JQ, Ni L, Scott CS, Retsch-Bogart GZ, Smith PC: Pharmacokinetics of ibuprofen enantiomers in children with cystic fibrosis. J Clin Pharmacol 2000;40:861-868.

32 Chivers JE, Gong W, King EM, Seybold J, Mak JC, Donnelly LE, Holden NS, Newton $\mathrm{R}$ : Analysis of the dissociated steroid RU24858 does not exclude a role for inducible genes in the anti-inflammatory actions of glucocorticoids. Mol Pharmacol 2006;70: 2084-2095.

33 LeVan TD, Behr FD, Adkins KK, Miesfeld RL, Bloom JW: Glucocorticoid receptor signaling in a bronchial epithelial cell line. Am J Physiol 1997;272:838-843.

-34 Nie M, Knox AJ, Pang L: $\beta_{2}$-Adrenoceptor agonists, like glucocorticoids, repress eotaxin gene transcription by selective inhibition of histone $\mathrm{H} 4$ acetylation. J Immunol 2005; 175:478-486.

35 Bartoszewski R, Rab A, Jurkuvenaite A, Mazur M, Wakefield J, Collawn JF, Bebok Z: Activation of the unfolded protein response by $\triangle$ F508 CFTR. Am J Respir Cell Mol Biol 2008;39:448-457.

36 Vij N, Fang S, Zeitlin PL: Selective inhibition of endoplasmic reticulum-associated degradation rescues $\Delta \mathrm{F} 508$-cystic fibrosis transmembrane regulator and suppresses interleukin-8 levels: therapeutic implications. Biol Chem 2006;281:17369-17378.

37 Marciniak SJ, Yun CY, Oyadomari S, Novoa I, Zhang Y, Jungreis R, Nagata K, Harding HP, Ron D: CHOP induces death by promoting protein synthesis and oxidation in the stressed endoplasmic reticulum. Genes Dev 2004; 18:3066-3077.

38 Vij N, Amoako MO, Mazur S, Zeitlin PL: CHOP transcription factor mediates IL-8 signaling in cystic fibrosis bronchial epithelial cells. Am J Respir Cell Mol Biol 2008;38: 176-184.

39 Furst SM, Khan KN, Komocsar WJ, Fan L, Mennear J: Screening new drugs for immunotoxic potential. II. Assessment of the effects of selective and nonselective COX-2 inhibitors on complement activation, superoxide anion production and leukocyte chemotaxis and migration through endothelial cells. J Immunotoxicol 2005;2:85-96.

40 Li J, Xiang YY, Ye L, Tsui LC, Macdonald JF, $\mathrm{Hu}$ J, Lu WY: Nonsteroidal anti-inflammatory drugs upregulate function of wild-type and mutant CFTR. Eur Respir J 2008;32: 334-343.
41 Chmiel JF, Berger M, Konstan MW: The role of inflammation in the pathophysiology of CF lung disease. Clin Rev Allergy Immunol 2002;23:5-27.

42 Jacquot J, Tabary O, Le RP, Clement A: Airway epithelial cell inflammatory signalling in cystic fibrosis. Int J Biochem Cell Biol 2008;40:1703-1715.

-43 Escotte S, Tabary O, Dusser D, Majer-Teboul C, Puchelle E, Jacquot J: Fluticasone reduces IL- 6 and IL- 8 production of cystic fibrosis bronchial epithelial cells via IKK-beta kinase pathway. Eur Respir J 2003;21:574-581.

44 Kube D, Sontich U, Fletcher D, Davis PB: Proinflammatory cytokine responses to $P$. aeruginosa infection in human airway epithelial cell lines. Am J Physiol Lung Cell Mol Physiol 2001;280:L493-L502.

-45 Fink J, Steer JH, Joyce DA, McWilliam AS, Stewart GA: Pro-inflammatory effects of Burkholderia cepacia on cystic fibrosis respiratory epithelium. FEMS Immunol Med Microbiol 2003;38:273-282.

-46 Tabary O, Zahm JM, Hinnrasky J, Couetil JP, Cornillet P, Guenounou M, Gaillard D, Puchelle E, Jacquot J: Selective up-regulation of chemokine IL-8 expression in cystic fibrosis bronchial gland cells in vivo and in vitro. Am J Pathol 1998;153:921-930.

-47 Kammouni W, Figarella C, Marchand S, Merten M: Altered cytokine production by cystic fibrosis tracheal gland serous cells. Infect Immun 1997;65:5176-5183.

-48 Engelhardt JF, Yankaskas JR, Ernst SA, Yang Y, Marino CR, Boucher RC, Cohn JA, Wilson JM: Submucosal glands are the predominant site of CFTR expression in the human bronchus. Nat Genet 1992;2:240-248.

-49 Lakshminarayanan V, Drab-Weiss EA, Roebuck KA: $\mathrm{H}_{2} \mathrm{O}_{2}$ and tumor necrosis factorainduce differential binding of the redoxresponsive transcription factors $\mathrm{AP}-1$ and NF- $\kappa \mathrm{B}$ to the interleukin- 8 promoter in endothelial and epithelial cells. J Biol Chem 1998;273:32670-32678.

-50 Park SK, Yang WS, Han NJ, Lee SK, Ahn H, Lee IK, Park JY, Lee KU, Lee JD: Dexamethasone regulates AP-1 to repress TNF- $\alpha$ induced MCP-1 production in human glomerular endothelial cells. Nephrol Dial Transplant 2004;19:312-319.

51 Mukaida N, Shiroo M, Matsushima K: Genomic structure of the human monocyte-derived neutrophil chemotactic factor IL-8. J Immunol 1989;143:1366-1371

-52 Chang MM, Juarez M, Hyde DM, Wu R: Mechanism of dexamethasone-mediated interleukin-8 gene suppression in cultured airway epithelial cells. Am J Physiol Lung Cell Mol Physiol 2001;280:L107-L115. 